\title{
Strategi Marketing UMKM di Desa Widoro Kecamatan Krejengan
}

\author{
${ }^{1}$ Adi Sutrisno, ${ }^{2}$ Sugeng Edy Mulyono, ${ }^{3} \mathrm{Hosnol}$ Wafa, ${ }^{4}$ Indra Tjahyadi \\ 1,2,3,4 Program Studi Bahasa Inggris, Universitas Panca Marga Probolinggo \\ adiearasy@gmail.com
}

\begin{abstract}
Abstrak: Tujuan Pengabdian Masyarakat ini dilakukan untuk peningkatan kapasitas Ipteks dalam promosi dan pemasaran UMKM Widoro Jaya di Kecamatan Krejengan Kabupaten Probolinggo. Urgensi dilakukannya Pengabdian Masyarakat ini disebabkan faktor Pandemi Covid-19 yang mempengaruhi penurunan kebertahanan UMKM di Kabupaten Probolinggo. Metode Pelaksanaan yang telah dilakukan dengan cara Pendampingan kegiatan pendataan produk, desain produk, desain pengemasan produk, dan pemasaran produk. Hasil dari kegiatan Pengabdian Masyarakat ini adalah pendataan produk yang tertata rapi, desain produk dan kemasan yang lebih memberikan daya tarik pada konsumen, serta terciptanya media atau sarana pemasaran baru berbasis teknologi informasi dan komunikasi digital dalam jaringan yang berdampak pada kemudahan akses pasar sasaran pada produk.
\end{abstract}

Kata kunci : strategi marketing, umkm, media sosial

Abstract: The purpose of this Community Service is to increase the capacity of science and technology in the promotion and marketing of Widoro Jaya SMEs in Krejengan District, Probolinggo Regency. The urgency of this Community Service is due to the Covid-19 Pandemic factor that affects the decline in the survival of MSMEs in Probolinggo Regency. The implementation method that has been carried out is by assisting in product data collection, product design, product packaging design, and product marketing activities. The results of this Community Service activity are neatly organized product data collection, product design and packaging that are more attractive to consumers, as well as the creation of new media or marketing tools based on digital information and communication technology in networks that have an impact on easy access to the target market for products.

Keywords: marketing strategy, msme, social media

\section{Pendahuluan}

UMKM Widoro Jaya merupakan salah satu Usaha Micro Kecil Menengah yang berada di Desa Widoro Kecamatan Krejengan Kabupaten Probolinggo yang sampai saat ini mampu bertahan di era pandemi ini. Bapak Naim Selaku pemilik UMKM Widoro Jaya mengatakan bahwa pada awal pandemi Covid-19 di Indonesia, sekitar bulan Maret hingga Mei bisnis rumahan yang dibangunnya sempat mengalami penurunan omzet. Terlebih saat diberlakukan PSBB di wilayah Probolinggo yang menyebabkan pesanan yang akan dikirim menjadi tersendat.

Hal tersebut akhirnya berdampak pada kegiatan operasional dimana lambat laun jumlah tenaga kerja yang semakin berkurang. Adapun Kondisi usaha UMKM Widoro pada tahun 2014-2018 menunjukkan peningkatan penjualan untuk masing-masing produknya. Produk yang di pasarkan yaitu Kembang goyang, Kripik Singkong, Ladrang, Kripik Pisang, Kripik Talas, Peyek. Namun akibat terjadinya PSBB yang terjadi sejak awal bulan maret 2019 maka jumlah penjualan semakin menurun dan jenis produk yang di pasarkan juga semakin berkurang. 
Tabel 1. Penurunan Jumlah Karyawan

\begin{tabular}{|c|c|c|c|c|c|c|c|c|c|c|c|c|c|c|c|}
\hline \multirow{2}{*}{ No } & \multirow{2}{*}{ Jenis Produk } & \multicolumn{7}{|c|}{ Jumlah Tenaga Kerja } & \multicolumn{7}{|c|}{ Penjualan } \\
\hline & & 2014 & 2015 & 2016 & 2017 & 2018 & 2019 & 2020 & 2014 & 2015 & 2016 & 2017 & 2018 & 2019 & 2020 \\
\hline 1 & Kembang Goyang & 2 & 3 & 4 & 5 & 4 & 2 & 2 & & & & & & & \\
\hline 2 & Kripik Singkong & 2 & 3 & 4 & 5 & 4 & 2 & 2 & & & & & & & \\
\hline 3 & Ladrang & 2 & 3 & 4 & 5 & 4 & 2 & 2 & & & & & & & \\
\hline 4 & Kripik Pisang & 2 & 3 & 4 & 5 & 4 & 2 & 2 & & & & & & & \\
\hline 5 & Kripik Talas & 2 & 3 & 4 & 5 & 4 & 2 & 2 & & & & & & & \\
\hline 6 & Peyek & 2 & 3 & 4 & 5 & 4 & 2 & 2 & & & & & & & \\
\hline 7 & Gettas & 2 & 3 & 4 & 5 & 4 & 2 & 2 & & & & & & & \\
\hline
\end{tabular}

Pemasaran adalah salah satu lini penting dalam bisnis, bagaimana sebuah produk diperkenalkan hingga didistribusikan hingga sampai pada tangan konsumen adalah salah satu tugas dari bagian pemasaran, saat ini terdapa banyak metode dan cara yang dapat digunakan untuk memasarkan sebuah produk barang atau jasa, namun seiring dengan perkembangan zaman para pemasar pun wajib mengubah pola dan taktik pemasaran agar tetap mampu mengikuti perkembangan jaman dan mampu bersaing di pasar bebas dengan para kompetitornya .

Pada era industri 4.0 atau lebih dikenal dengan era digital, sangat mudah dijumpai bagaimana bisnis kini memenuhi keinginan pelanggan melalui penggunaan jasa yang ada. Jika ditelusuri bahwa para ibu rumah tangga bisa melakukan bisnis online dari rumah hanya menggunakan paket data dan android (gadget). Secara gambaran umum, UMKM Widoro Jaya memiliki keterbatasan didalam penguasaan teknologi informasi. Sementara tuntutan kebutuhan atas penggunaan dan penguasaan teknologi informasi tersebut sudah terasa semakin mendesak mengingat tingkat persaingan di pasar lokal, regional maupun global. Pada era tersebut, setiap pelaku usaha sudah mulai dituntut untuk mampu menyajikan informasi secara cepat dan akurat kepada pelanggannya. Dengan demikian, masyarakat juga dituntut untuk mampu dengan segera merespon secara cepat atas permintaan dan tuntutan pelanggannya.

Strategi pemasaran diperlukan pada berbagai lini produk dan jasa. Strategi pemasaran merupakan garda terdepan berlangsungnya sebuah perusahaan. Hak tersebut disebabkan strategi pemasaran memiliki peran yang penting bagi perusahaan untuk membantu menerapkan taktik agar menjadi perusahaan yang sukses (Mashuri, 2019). Ketepatan dalam pemilihan strategi pemasaran tidak saja dapat menunjang ketercapaian target penjualan, tetapi juga dapat memperbaiki kredibilitas perusahaan (Utama, 2019). Maka, strategi pemasaran yang efektif dan efisien sangat diperlukan oleh perusahaan.

Berdasarkan hasil pengamatan yang terjadi dilapangan bahwa strategi pemasaran yang digunakan oleh pemilik usah UMKM widoro jaya masih berkutat pada system non digital. Maka dapat diidentifikasi adanya permasalahan atau kebutuhan guna solusi dari UMKM 
Widoro Jaya, Butuhnya strategi pemasaran yang tepat dalam rangka mempertahankan pemasaran hasil produksi ke pangsa pasar.

Berdasarkan paparan di atas, maka artikel memfokuskan kajiannya pada strategi yang digunakan oleh pemasar untuk memaksimalkan barang dagangannya melalui sistem digital di era 4.0. Strategi pemasaran yang dimaksud adalah memasarkan produk UMKM Indonesia. Target dari hasil Pengabdian Universitas ini membawa dampak positif kepada pelaku UMKM widoro.

\section{Metode}

Metode yang digunakan dalam kegiatan Pengabdian Masyarakat ini adalah metode pendampingan. Metode kegiatan pengabdian ini sebagai berikut:

a. Pendampingan Pendataan Produk

Pada tahapan ini, dilakukan pencarian informasi dan data-data yang tepat dari beberapa produk yang ada untuk pembaharuan Pembaharuan.

b. Desain Label dan Kemasan.

membuatkan desain label kemasan produk agar terlihat lebih menarik dan juga memberikan beberapa informasi di label produk mengenai kontak untuk pemesanan.

c. Pendampingan pemasaran Produk UMKM Widoro Jaya.

melakukan bimbingan pada pelaku UMKM terkait pemasaran yang relevan saat ini yang bisa dilakukan.

\section{Hasil dan Pembahasan}

Virus Corona telah mencuri perhatian seluruh warga dunia. Munculnya Virus Corona telah berdampak pada berbagai lini kehidupan, tak terkecuali pada pelaku bisnis usaha mikro kecil dan menengah atau UMKM. Melalui wawancara yang telah penulis lakukan bermula dari Virus Corona yang dianggap menghambat proses bisnis UMKM widoro jaya yang berlokasi di desa widoro kecamatan probolinggo karena pekerjaan yang biasanya dilakukan dengan bertatap muka menjadi sulit dilakukan. Dalam kondisi tesebut maka solusi yang bisa dilakukan adalah metode perekonomian yang bersifat jangka pendek sebagai pertahanan bagi UMKM. Selanjutnya solusi jangka pendek tersebut perlu dilanjutkan dengan solusi jangka panjang. Secara umum tentang definisi pemasaran itu adalah kegiatan memanfaatkan variabel-variabel penjualan untuk mendatangkan konsumen, meningkatkan penjualan, dan menjaga hubungan baik dengan konsumen sehingga kegiatan transaksi yang terjadi dapat dilakukan secara terus menerus dan berkesinambungan 
Adapun yang dilakukan dalam strategi pemasaran dalam mempertahankan perekonomian di era pandemi dan digital saat ini bertujuan mendukung aktivitas atau kegiatan peningkatan perluasan ekonomi. Kegiatan atau aktivisan perluasan ekonomi yang dilakukan oleh UMKM Widoro Jaya di era pandemi sebagai berikut:

A. Inovasi produk dan packaging menarik.

Salah satu faktor yang diduga mempengaruhi minat beli konsumen adalah inovasi produk. Konsumen cenderung membandingkan terlebih dahulu produk yang akan dibeli olehnya dengan produk yang ditawarkan oleh produsen lain. Oleh karena itu, dengan adanya inovasi atas produk yang dibuat diharapkan menarik minat beli konsumen.

Dalam hal ini,untuk UMKM widoro Jaya dilakukan langkah baru sebagai langkah yang solutif bagi peningkatan UMKM itu sendiri seperti pembaharuan label, membuat logo usaha yang di tampilkan pada label serta mendesain ulang label agar terlihat lebih menarik pada Produk UMKM Widoro Jaya. Untuk memberikan peningakatan perluasan pemasaran dicantumkan juga gambar sosial media dan nomor HP pemilik UMKM Widoro Jaya agar lebih mudah dikenal dan lebih mudah berkomunikasi dengan masyarakat luas.

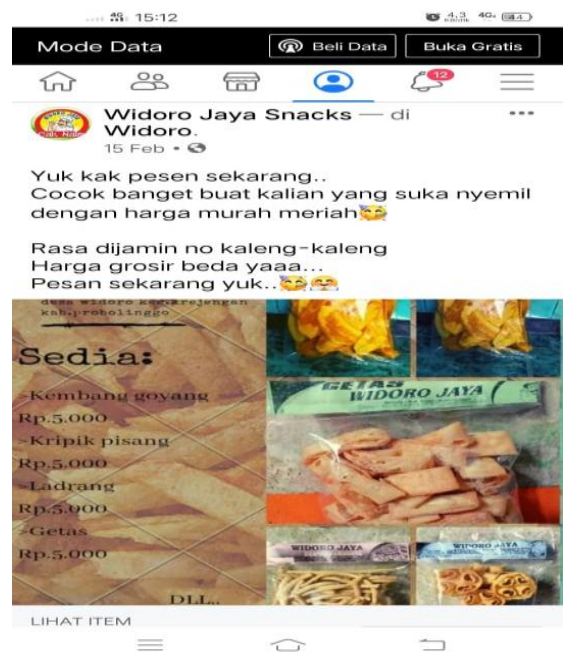

Gb. 1 pemasaran melalui facebook

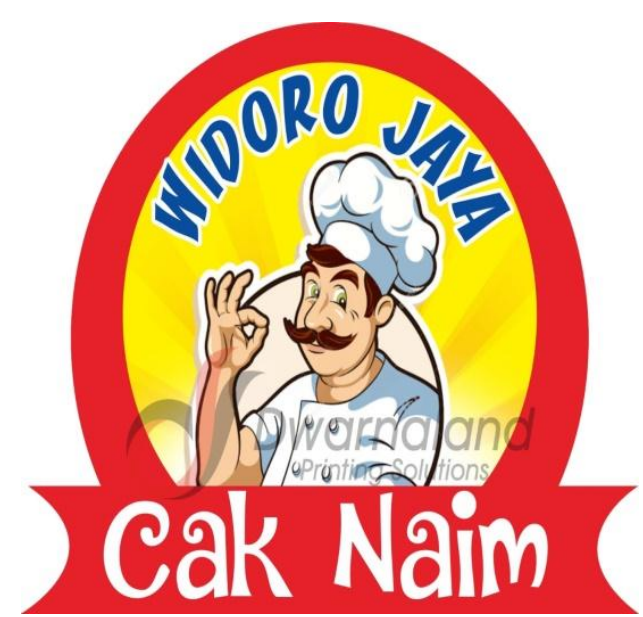

Gambar 2 Pembuatan logo UMKM

B. Memaksimalkan penggunaan Medsos Bisnis.

Kondisi social distancing yang sedang dilakukan masyarakat saat ini sebagai upaya memutus mata rantai jumlah penyebaran virus corona. Media sosial merupakan tempat strategis bagi promosi dan pemasaran produk di masa pandemi. Ketersediaan fasilitas yang dimiliki oleh sosial media daring untuk melakukan penjarakan sosial dan fisik membuat media tersebut relevan digunakan pada masa pandemi. Maka dari itu perlu memaksimalkan media sosial bisnis untuk mengenalkan produk. Hal tersebut sebagaimana tampak pada ganbar berikut. 


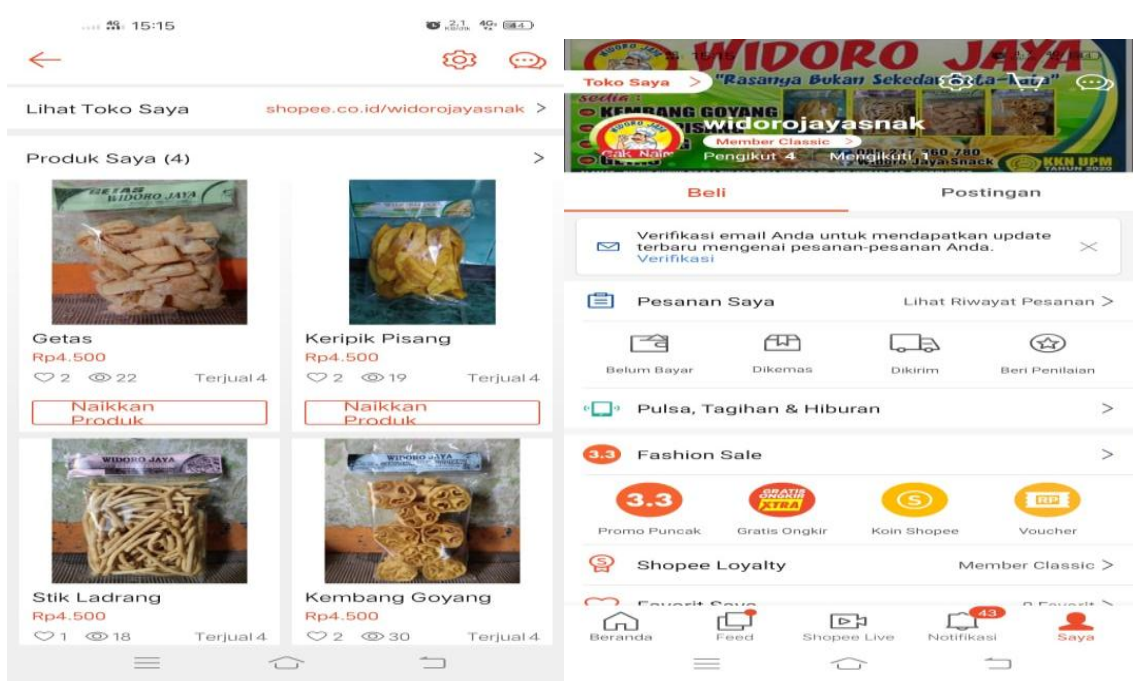

Gambar 3

Pemasaran melalui e-Commerce

Mulai dari nama akun, keterangan biodata, konten, caption, hastag perlu dipikirkan untuk menarik awareness dan engagement. Pemanfaatan media sosial tidak hanya dipandang sebagai sarana untuk aktualisasi diri namun dapat berkembang kearah dunia bisnis salah satunya adalah media sosial dapat menjadi sarana pemasaran itu sendiri.

Pemanfaat media sosial pada pemasaran itu bisa dilakuakan dalam berbagai banyak hal seperti Instagram, dan facebook. Selain itu, itu pemasaran bisa dilakuakan dengan media social e-commerce seperti shoppe, buka lapak dal lain-lain. Dalam hal ini, untuk UMKM Widoro Jaya hanya meliputi Akun Facebook dan Akun Shopee. Media facebook lebih popular dikalangan masyarakat karena lebih mudah digunakan dan paling banyak di akses oleh masyarakat. Tingginya jumlah pengguna facebook akan memudahkan konsumen untuk mengenal UMKM Widoro Jaya sehingga memungkinkan untuk berjualan selama 24 jam penuh dalam sehari, selama 7 hari dalam seminggu. Sedangkan ketika berjualan di akun Shopee banyak keuntungan yang diperoleh seperti gratis ongkos kirim dengan minimal pembelian, terhubung dengan sistem pengiriman paket dan pangsa pasar lebih luas. Pada kesempatan lain pemasaran produk juga dilakukan melalui via Whatsapp.

\section{Kesimpulan}

Metode pendampingan efektif dan efisien dalam meningkatkan kinerja UMKM di Desa Widoro Kecamatan Krejengan. Hal tersebut karena melalui metode pendampingan subjek sasaran bisa memperoleh pemahaman secara mendalam. Hal tersebut menyebabkan tujuan kegiatan berupa peningkatan pemasaran melalui media sosial daring dapat dicapai. Hal 
tersebut tampak pada peningkatan pemesanan produk melalui media sosial pemasaran daring yang dimiliki oleh UMKM Widoro Jaya.

\section{Ucapan Terima Kasih}

Kegiatan Pengabdian Masyarakat ini terlaksana atas dukungan yang luar biasa oleh Kepala Desa Desa Widoro Kecamatan Krejengan, Camat Kecamatan Krejengan, dan Rektor Universitas Panca Marga, serta UMKM Widoro Jaya, untuk itu kami mengucapkan terima kasih sebesar-besarnya.

\section{Referensi}

Antara. (n.d.). 4 Sektor yang Paling Tertekan Akibat Corona Menurut Sri Mulyani. Tempo.Co. Retrieved June 20, 2021, from https://bisnis.tempo.co/read/1326504/4sektor-yang-paling-tertekan-akibat-corona-menurut-sri-mulyani

Mashuri. (2019). ANALISIS STRATEGI PEMASARAN UMKM DI ERA 4.0. Jurnal IQTISHADUNA, 8(2), 215-224.

https://doi.org/https://doi.org/10.46367/iqtishaduna.v8i2.175

Putri, G. S. (n.d.). WHO Resmi Sebut Virus Corona Covid-19 sebagai Pandemi Global. Kompas.Com. Retrieved June 20, 2021, from https://www.kompas.com/sains/read/2020/03/12/083129823/who-resmi-sebut-viruscorona-covid-19-sebagai-pandemi-global?page=all

Utama, I. D. (2019). Analisis Strategi Pemasaran Pada Usaha Mikro Kecil dan Menengah (UMKM) Pada Era Digital di Kota Bandung. EQUILIBRIUM: Jurnal IImiah Ekonomi Dan Pembelajarannya, 71 , 1. https://doi.org/10.25273/equilibrium.v7i1.3829 